\title{
Immunohistochemical Investigation of Lactoferrin in Human Bone Primary and Metastatic Tumours
}

\section{A. Ieni, V. Barresi, G. Speciale, R.A. Caruso and G. Tuccari*}

Department of Human Pathology "Gaetano Barresi", Section of Pathological Anatomy, University of Messina, Italy

\section{Abstract}

Background: Lactoferrin (LF), an iron-binding glycoprotein, has a multifunctional role in humans, specifically in the regulation of iron homeostasis, host defense against infections and inflammations, even if some experimental studies attributed others activities to LF, such as cellular differentiation, regulation growth, protection against cancer development and metastases.

Methods: We performed herein an immunohistochemical analysis of LF in a cohort of primary and metastatic neoplasms occurred in the bone by using a monoclonal specific antibody. LF reactivity was quantified using an intensity- distribution (ID) score.

Results: In primary bone tumours, LF immunostaining as whole was evident in 21/82 cases (25.60\%), either benign or malignant. About bone metastatic lesions, LF immunopositivity was encountered in $14 / 30$ cases (46.6\%), mainly due to prostatic, renal, uterine and colonic carcinomas, while the positivity was reduced in metastases from breast carcinomas and it was completely absent in lung cancer.

Conclusion: On the light of these results, we suggest that neoplastic elements might produce LF in order to make a greater amount of iron available for their turnover. Additional analyses are needed concerning new applications of LF in clinical oncology either for its nutraceutical function either for its capability to potentiate chemotherapy.

\section{Introduction}

Lactoferrin $(\mathrm{LF})$ is a multi-function globular protein $(80 \mathrm{KDa})$ present in many biological fluids such as colostrum. Milk, plasma, bile, amniotic fluid, urine, tears and saliva [1-2]; moreover, it represents a peculiar component of secondary granules of neutrophils [3]. By its capability to bind iron, LF exhibits a broad spectrum of biological activities such as antimicrobic [4-6] or anti-mycotic, antiparasitic and anti-viral [7-11]. Together with this well documented iron-chelating activity, LF is able to modulate inflammatory processes by an anti-oxydative action [12-14]; more recently, it has been shown that Lf promotes the bone growth stimulating the proliferation and differentiation of osteoblasts and inhibiting their apoptosis as well as osteoclastogenesis [15-17]. Finally, it has been suggested that LF is able to inhibit cellular proliferation with a suppressive effect on tumours, either in vitro either in vivo $[2,11,18-20]$, although the effective molecular mechanism is still unclear.

In normal human adult and fetal tissues, LF has been immunohistochemically documented in many organs such as kidney, stomach, pancreas, salivary glands, liver, bone marrow and skin [2,21]; moreover, LF immunoreactivity has been also reported in embryo-fetal bone and cartilage tissues, but not in adult ones [22-24]. However, in human neoplastic conditions, LF has been extensively investigated in order to correlate its presence with the pattern of other functional neoplastic markers as well as to determine its possible prognostic role in tumors [25-26]. Therefore, we have thought to be of interest to report herein an immunohistochemical analysis of LF in a cohort of primary and metastatic neoplasms occurred in the bone by using a monoclonal specific antibody.

\section{Materials and Methods}

LF immunoexpression was investigated in one hundred twelve neoplastic specimens, of which 82 human primary bone and cartilage and 30 bone metastatic lesions obtained through curettage or surgery from an equal number of patients ( 59 males, 53 females; age range 9-92 years; mean age 41.02 years). The cohort was represent by 10 giant cell tumours (GCT), 7 osteoid osteomas (OO), 6 ossifying fibromas (OF), 34 enchondromas (EC), 6 osteochondromas (OC), 5 chondroblastomas
(CBL), 5 chondrosarcomas (CS) $\overline{\text { (three chondroblastic type and two }}$ chondroid type), 3 chondromixoyd fibromas (CMF), 3 osteosarcomas (OS), 1 myeloma and 2 adamantinomas; moreover, bone metastases, surgically taken were obtained from files of our Department, the primary carcinomas of which included breast (10 cases), prostate ( 6 cases), kidney (4 cases), lung (4 cases), colon ( 2 cases) and uterus (4 cases). Data concerning the site of occurrence of primary bone tumours as well as the primary corresponding carcinomas producing bone metastases were available.

Samples of unaffected human bone and cartilage tissues were taken at autopsy from 25 fetuses (ranging from 8-34 weeks of gestation), nine of which obtained from fetuses below the 13th week of gestation by legal voluntary termination of pregnancy. Moreover, normal bone and cartilaginous specimens were taken at autopsy from ten adult (mean age 70.4 years) after death from vascular accidents. All these bone fragments were utilized as tissue controls.

The patient's personal details were non-identifiable and all the patients had provided written consent to their medical information being used for research purposes, according with the Helsinki declaration.

All samples were fixed in $10 \%$ neutral formalin for $24 \mathrm{~h}$ at room temperature (RT) and then embedded in paraffin at $56^{\circ} \mathrm{C}$. When neoplastic samples exhibited areas of mineralization, a decalcification procedure using formic acid 5\% or EDTA 5\%, pH 7.4, for a period not longer than 24 hours was performed. From each tissue block,

"Corresponding Author: Prof. Giovanni Tuccari, Department of Human Pathology "Gaetano Barresi" Azienda Ospedaliera Universitaria "Policlinico G. Martino", Via Consolare Valeria, 1 - 98125 Messina, Italy, Tel: 39+090+2212539; Fax 39+090-2928150; E-mail: tuccari@unime.it

Citation: leni A, Barresi V, Speciale G, Caruso RA, Tuccari G (2015) Immunohistochemical Investigation of Lactoferrin in Human Bone Primary and Metastatic Tumours. Int J Lab Med Res 1: 105. doi: http://dx.doi. org/10.15344/2455-4006/2015/105

Copyright: @ 2015 Leni et al. This is an open-access article distributed under the terms of the Creative Commons Attribution License, which permits unrestricted use, distribution, and reproduction in any medium, provided the original author and source are credited. 
Citation: Ieni A, Barresi V, Speciale G, Caruso RA, Tuccari G (2015) Immunohistochemical Investigation of Lactoferrin in Human Bone Primary and Metastatic Tumours. Int J Lab Med Res 1: 105. doi: http://dx.doi.org/10.15344/2455-4006/2015/105

Page 2 of 6

4 - $\mu \mathrm{m}$-thick sections were cut and mounted on silane-coated glasses, then dewaxed in xylene and rehydrated in graded ethanols. Parallel sections were stained routinely with haematoxylin/heosin and with Perls' Prussian blue ferrocyanide. Antigen retrieval, by heating slides placed in $0.01 \mathrm{M}$ citrate buffer $\mathrm{Ph} 6.0$ in a microwave oven for 3 cycles $\mathrm{x} 5 \mathrm{~min}$, was performed before adding primary antibodies. For the immunohistochemical study, sections were treated in a moist chamber: 1) with $0.1 \% \mathrm{H}_{2} \mathrm{O}_{2}$ in methanol to block the intrinsic peroxidase activity ( $30 \mathrm{~min}$ at $\mathrm{RT}$ ); 2 ) with normal sheep serum to prevent unspecific adherence of serum proteins; 3 ) with monoclonal primary antibodies against (anti-human) LF (Clone 1A1; Biodesign International, USA; w.d. 1:75; 60 min at RT) and Ki-67 antigen (MIB-1; DakoCytomation; 1:200) 4) with sheep anti-mouse immunoglobulin antiserum (Behring Institute; w.d. 1:25; $30 \mathrm{~min}$ at RT); 5) with mouse anti-horseradish peroxidase-antiperoxidase complexes (Dako Cytomation; w.d. 1:25; $30 \mathrm{~min}$ at RT). For the demonstration of peroxidase activity the sections were incubated in darkness for $10 \mathrm{~min}$ with 3-3' diaminobenzidine tetra hydrochloride (Sigma Chemical Co., St Louis, MO, USA), in the amount of $100 \mathrm{mg}$ in $200 \mathrm{ml}$ 0,03\% hydrogen peroxide in phosphate-buffered saline (PBS). The nuclear counterstaining was performed by Mayer's haemalum.

Finally, to test the inter-run variability of LF immunostaining, renal tubular structures within normal kidney samples as well as portions of the parotid gland were utilized as positive control in every run. To test the specificity of LF immunostaining in order to deny the possibility of non-specific reaction, serial sections of each affected specimen were tested by replacing the specific antiserum by either PBS, normal rabbit serum or absorbing with excess of purified human LF from human liver and spleen (Sigma Chemical Co.) as well as with pre-absorbed primary antibody: the obtained results were negative.

Immunostained sections were estimated by light microscopy using a $\mathrm{x} 20$ and $\mathrm{x} 40$ objective lens and $\mathrm{x} 10$ eyepiece. Two pathologists using a double-headed microscope performed the assessment of LF immunostained sections on a consensus basis. The percentage of stained neoplastic cells (area of staining positivity: ASP) was graded as follows: 0 (no staining); 1 (>0 to $5 \%$ ); 2 ( $>5$ to $50 \%$ ) and $3(>50 \%$ ). In addition, the intensity of staining (IS) (weak $=1$; moderate $=2$; strong=3) was also taken into consideration. Successively, a LF intensity-distribution (ID) score was calculated for each case by multiplying the values of the ASP and the IS, according to that elsewhere reported in literature [27].

Ki-67 staining score, revealed by MIB-1 antibody, was evaluated by counting the percentage of positive nuclei per 1000 neoplastic cells in up to 10 representative fields of the whole neoplastic portions; all degrees of nuclear staining intensity were taken into consideration. The median labelling index ( $\mathrm{LI})(\mathrm{Ki}-67 \mathrm{LI}=2 \%)$ was utilized as the cutoff point to determine low and high Ki-67 expression.

Since the measurement of how many people know about different aspects of HIV/AIDS is crucial for designing proper prevention tools, especially for those who may be in contact with infected individuals and patients with AIDS.

The possible statistical correlations between LF immunoexpression and clinico-pathologicalparameters (ageand sex of thepatient, site of the tumours) as well as the Ki-67 LI were investigated using Chi-squared test or the Fisher's exact Test, as appropriate. Probability $(\mathrm{P})$ values less than 0.05 were considered to be statistically significant. Data were analysed using the SPSS package version 6.1.3 (SPSS Inc., Chicago, IL, USA).

\section{Results}

Routinely stained hematoxylin-eosin sections revealed an adequate morphology, allowing to confirm the histologic diagnosis in all examined cases. either in the primary neoplastic lesions as well as in the bone metastatic deposits.

In primary bone tumours, LF immunoreactivity as whole was evident in $21 / 82$ cases $(25.60 \%)$, independently from Perls' reactive deposits; in detail, with a variable ID-score, LF immunolocalization was encountered in 10/10 GCT (Figure-1a), 5/7 OO (Figur-1b), 0/6 OF, 0/34 EC, 0/6 OC, 3/5 CBL, 0/5 CS (Figure-1c), 3/3 CMF, 0/3 OS (Fig.1d), 1/1 myeloma and 2/2 adamantinomas (Table-1). Regarding bone metastatic lesions, LF immunostaining was encountered in 14/30 cases $(46.6 \%)$, mainly due to prostatic, renal (Figure-2a), uterine and colonic carcinomas, while the positivity was reduced in metastases from breast carcinomas (Figure-2b) and it was completely absent in lung cancer (Table 2).

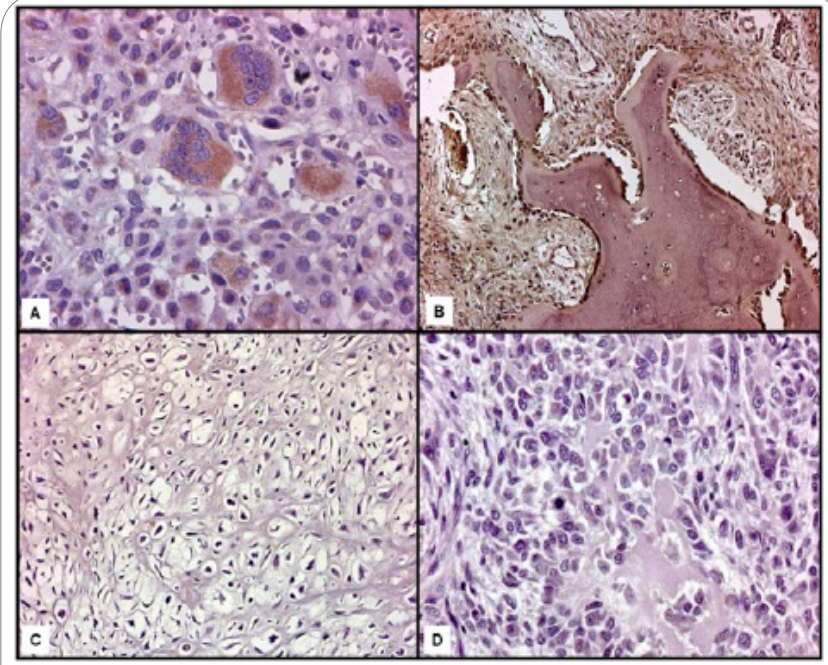

Figure 1: LF immunostaining was evident in giant elements within GCT (a, $\mathrm{x} 400)$; osteoblats present within OO were also immunoreactive (b, x200)(Mayer's hemalum counterstain).

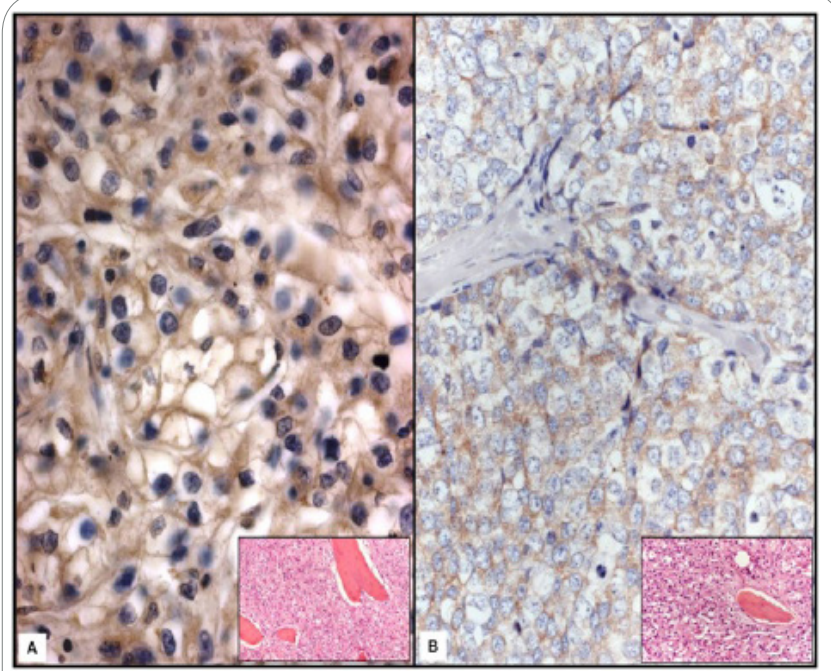

Figure 2: LF immunopositivity was well represented at the periphery of clear cell in a metastasis to bone by renal carcinoma ( $a, x 400)$; the inset illustrated the routinely stained section with partially destroyed bone lamellae (x 40). A light to moderate LF immunostaining was found in breast ductal invasive carcinoma (b, $\mathrm{x} 400$ ); the inset illustrated the routinely stained section with partially destroyed bone lamellae (x 40). (Mayer's hemalum counterstain). 
Citation: Ieni A, Barresi V, Speciale G, Caruso RA, Tuccari G (2015) Immunohistochemical Investigation of Lactoferrin in Human Bone Primary and Metastatic Tumours. Int J Lab Med Res 1: 105. doi: http://dx.doi.org/10.15344/2455-4006/2015/105

Page 3 of 6

\begin{tabular}{|c|c|c|c|c|c|c|c|c|c|c|c|}
\hline Case & Localization & Histotype & LF ASP & LF IS & LF ID score & Case & Localization & Histotype & LF ASP & LF IS & LF ID score \\
\hline 1 & Humerus & EC & 0 & 0 & 0 & 42 & Humerus & CS & 0 & 0 & 0 \\
\hline 2 & Tibia & EC & 0 & 0 & 0 & 43 & Humerus & CS & 0 & 0 & 0 \\
\hline 3 & Hand & $\mathrm{EC}$ & 0 & 0 & 0 & 44 & Femur & CS & 0 & 0 & 0 \\
\hline 4 & Femur & EC & 0 & 0 & 0 & 45 & Humerus & CS & 0 & 0 & 0 \\
\hline 5 & Femur & EC & 0 & 0 & 0 & 46 & Femur & CBL & 2 & 1 & 2 \\
\hline 6 & Hand & $\mathrm{EC}$ & 0 & 0 & 0 & 47 & Humerus & $\mathrm{CBL}$ & 1 & 2 & 2 \\
\hline 7 & Hand & EC & 0 & 0 & 0 & 48 & Humerus & CBL & 2 & 1 & 2 \\
\hline 8 & Hand & $\mathrm{EC}$ & 0 & 0 & 0 & 49 & Femur & CBL & 1 & 2 & 2 \\
\hline 9 & Femur & EC & 0 & 0 & 0 & 50 & Humerus & CBL & 2 & 1 & 2 \\
\hline 10 & Hand & $\mathrm{EC}$ & 0 & 0 & 0 & 51 & Tibia & $\mathrm{CMF}$ & 2 & 2 & 4 \\
\hline 11 & Femur & EC & 0 & 0 & 0 & 52 & Tibia & $\mathrm{CMF}$ & 2 & 2 & 4 \\
\hline 12 & Sternum & $\mathrm{EC}$ & 0 & 0 & 0 & 53 & Femur & $\mathrm{CMF}$ & 1 & 1 & 1 \\
\hline 13 & Pelvis & EC & 0 & 0 & 0 & 54 & Tibia & $\mathrm{OO}$ & 2 & 3 & 6 \\
\hline 14 & Femur & EC & 0 & 0 & 0 & 55 & Fibula & $\mathrm{OO}$ & 2 & 2 & 4 \\
\hline 15 & Hand & $\mathrm{EC}$ & 0 & 0 & 0 & 56 & Femur & $\mathrm{OO}$ & 2 & 2 & 4 \\
\hline 16 & Hand & $\mathrm{EC}$ & 0 & 0 & 0 & 57 & Fibula & $\mathrm{OO}$ & 2 & 1 & 2 \\
\hline 17 & Hand & $\mathrm{EC}$ & 0 & 0 & 0 & 58 & Fibula & $\mathrm{OO}$ & 2 & 1 & 2 \\
\hline 18 & Hand & EC & 0 & 0 & 0 & 59 & Femur & $\mathrm{OO}$ & 0 & 0 & 0 \\
\hline 19 & Femur & $\mathrm{EC}$ & 0 & 0 & 0 & 60 & Fibula & $\mathrm{OO}$ & 0 & 0 & 0 \\
\hline 20 & Hand & EC & 0 & 0 & 0 & 61 & Hand & GCT & 3 & 2 & 6 \\
\hline 21 & Femur & $\mathrm{EC}$ & 0 & 0 & 0 & 62 & Femur & GCT & 2 & 3 & 6 \\
\hline 22 & Sternum & EC & 0 & 0 & 0 & 63 & Hand & GCT & 2 & 2 & 4 \\
\hline 23 & Pelvis & $\mathrm{EC}$ & 0 & 0 & 0 & 64 & Hand & GCT & 2 & 2 & 4 \\
\hline 24 & Femur & EC & 0 & 0 & 0 & 65 & Femur & GCT & 2 & 2 & 4 \\
\hline 25 & Hand & EC & 0 & 0 & 0 & 66 & Hand & GCT & 2 & 2 & 4 \\
\hline 26 & Hand & EC & 0 & 0 & 0 & 67 & Pelvis & GCT & 2 & 2 & 4 \\
\hline 27 & Femur & EC & 0 & 0 & 0 & 68 & Tibia & GCT & 2 & 1 & 2 \\
\hline 28 & Sternum & $\mathrm{EC}$ & 0 & 0 & 0 & 69 & Hand & GCT & 1 & 1 & 1 \\
\hline 29 & Humerus & EC & 0 & 0 & 0 & 70 & Femur & GCT & 1 & 1 & 1 \\
\hline 30 & Tibia & EC & 0 & 0 & 0 & 71 & Femur & OS & 0 & 0 & 0 \\
\hline 31 & Hand & $\mathrm{EC}$ & 0 & 0 & 0 & 72 & Femur & OS & 0 & 0 & 0 \\
\hline 32 & Hand & $\mathrm{EC}$ & 0 & 0 & 0 & 73 & Femur & OS & 0 & 0 & 0 \\
\hline 33 & Pelvis & EC & 0 & 0 & 0 & 74 & Femur & OF & 0 & 0 & 0 \\
\hline 34 & Pelvis & EC & 0 & 0 & 0 & 75 & Femur & OF & 0 & 0 & 0 \\
\hline 35 & Femur & OC & 0 & 0 & 0 & 76 & Hand & OF & 0 & 0 & 0 \\
\hline 36 & Hand & OC & 0 & 0 & 0 & 77 & Tibia & OF & 0 & 0 & 0 \\
\hline 37 & Rib & OC & 0 & 0 & 0 & 78 & Femur & OF & 0 & 0 & 0 \\
\hline 38 & Hand & OC & 0 & 0 & 0 & 79 & Femur & OF & 0 & 0 & 0 \\
\hline 39 & Hand & OC & 0 & 0 & 0 & 80 & Femur & Myeloma & 2 & 2 & 4 \\
\hline 40 & Humerus & OC & 0 & 0 & 0 & 81 & Tibia & Adamantinoma & 2 & 2 & 4 \\
\hline 41 & Jaw & CS & 0 & 0 & 0 & 82 & Tibia & Adamantinoma & 1 & 2 & 2 \\
\hline
\end{tabular}

Table 1: Lf immunohistochemical data referred to 82 analyzed bone tumours.

OO: osteoid osteoma, OC: osteochondroma, EC: enchondroma, GCT: giant cell tumour, CS: chondrosarcoma,

OS: osteosarcoma, OF: ossifying fibroma, CBL: chondroblastoma, CMF: chondromixoyd fibroma

LF: lactoferrin, ASP: area of staining positivity, IS: intensity of staining, ID: intensity distribution.

In all cases the LF immunostaining was mainly localized in the cytoplasm of the neoplastic elements and occasionally in the nuclei of the same cells.

With reference to the normal foetal bone-cartilage tissue, LF immunolabelling was found in all foetuses and it was mainly localized in the osteoblasts present in the calcified cartilage area as well as in

the nucleus of condrocytes encountered in the cartilage matrix adjacent to the calcified area; a considerable decrease of LF immunostaining was encountered by $24^{\text {th }}$ and up to $29^{\text {th }}$ week of gestation. In addition, no LF expression was in osteocartilagineous tissue after the $30^{\text {th }}$ week and up to $34^{\text {th }}$ week, similarly to that observed in all adult bonecartilage tissue samples. 
Citation: Ieni A, Barresi V, Speciale G, Caruso RA, Tuccari G (2015) Immunohistochemical Investigation of Lactoferrin in Human Bone Primary and Metastatic Tumours. Int J Lab Med Res 1: 105. doi: http://dx.doi.org/10.15344/2455-4006/2015/105

Page 4 of 6

\begin{tabular}{|l|l|l|l|l|l|}
\hline Case & Primitive & $\begin{array}{l}\text { Metastatic } \\
\text { Localization }\end{array}$ & LF ASP & LF IS & LF ID score \\
\hline 1 & Breast & Femur & 1 & 1 & 1 \\
\hline 2 & Prostate & Femur & 2 & 2 & 4 \\
\hline 3 & Breast & Humerus & 1 & 1 & 1 \\
\hline 4 & Breast & Femur & 2 & 2 & 4 \\
\hline 5 & Endometrium & Vertebra & 2 & 2 & 4 \\
\hline 6 & Colon & Femur & 1 & 2 & 2 \\
\hline 7 & Breast & Femur & 0 & 0 & 0 \\
\hline 8 & Lung & Sterno & 0 & 0 & 0 \\
\hline 9 & Lung & Femur & 0 & 0 & 0 \\
\hline 10 & Breast & Femur & 1 & 1 & 1 \\
\hline 11 & Lung & Fibula & 0 & 0 & 0 \\
\hline 12 & Kidney & Femur & 2 & 3 & 6 \\
\hline 13 & Endometrium & Humerus & 3 & 2 & 6 \\
\hline 14 & Breast & Vertebra & 0 & 0 & 0 \\
\hline 15 & Colon & Femur & 2 & 1 & 2 \\
\hline 16 & Endometrium & Femur & 1 & 1 & 1 \\
\hline 17 & Prostate & Pelvis & 1 & 2 & 2 \\
\hline 18 & Breast & Vertebra & 1 & 2 & 2 \\
\hline 19 & Kidney & Femur & 2 & 2 & 4 \\
\hline 20 & Prostate & Vertebra & 2 & 2 & 4 \\
\hline 21 & Prostate & Femur & 1 & 2 & 2 \\
\hline 22 & Breast & Femur & 1 & 1 & 1 \\
\hline 23 & Breast & Vertebra & 0 & 0 & 0 \\
\hline 24 & Prostate & Femur & 2 & 2 & 4 \\
\hline 25 & Prostate & Vertebra & 1 & 2 & 2 \\
\hline 26 & Breast & Femur & 1 & 1 & 1 \\
\hline 27 & Endometrium & Pelvis & 2 & 1 & 2 \\
\hline 28 & Kidney & Vertebra & 2 & 2 & 4 \\
\hline 29 & Kidney & Pelvis & 3 & 2 & 6 \\
\hline 30 & Lung & Femur & 0 & 0 & 0 \\
\hline & Lem & & & \\
\hline
\end{tabular}

Table 2: LF immunohistochemical results regarding bone metastases.

LF: Lactoferrin, ASP: Area of Staining Positivity, IS: Intensity of Staining, ID: Intensity Distribution.

LF was evident in renal tubular structures, parotid ductular/acinar portions as well as in secondary granules of neutrophils utilized as positive controls.

No statistical correlations between LF immunoreactivity and the other investigated parameters, including age, gender, site of lesions as well as Ki67 LI.

\section{Discussion}

A variable immunohistochemical expression has been previously elsewhere reported in various human neoplasms, such as carcinomas of the parotid [28], prostate [29], breast [30,31], thyroid [32-34], stomach [35], colon-rectum [36], gallbladder [37], astrocytomas and multiforme glioblastomas [38], skin [39], endometrium [40] and kidney [20].

Recently, it has been documented an improvement of bone health

by the use of LF, since this iron-binding protein stimulates the proliferation, differentiation and survival of osteoblast, significantly increasing the mineral apposition and bone formation [16-17,26,41]. In the corresponding pathologic neoplastic bone and cartilage samples, we have already reported some intriguing findings regarding LF immunoreactivity in small cohorts [22-24]. In the present study we have performed a systematic investigation regarding LF immunostaining in primary and metastatic bone tumours. Although LF immunolocalization exhibited a variable intensity-distribution score, CBL, CMF, GCT, OO, myeloma as well as adamantinoma appeared to be reactive, while no staining was detected in EC, OC, OF, CS as well OS. However, the appearance of LF in foetal bone tissue allowed to hypothesize a potential role for LF as oncofetal marker [25]; nevertheless, the quite heterogeneous distribution of LF in bone tumours as well as its independent presence in relation to the biological behaviour seem to be in contrast with the above mentioned role.

Moreover, we have immunohistochemically detected a variable amount of LF in metastatic neoplastic bone lesions of $14 / 30$ cases, mostly attributable to primitive prostatic, renal, uterine and colonic carcinomas, while its positivity appeared to be gradually reduced in secondary deposits from breast carcinomas and, finally, it was completely absent in lung cancer. It should be hypothesized that the negative LF immunoreactivity in small metastatic cohorts was correlated with undifferentiated or less differentiated variants of primary carcinomas $[2,20,26,40,42]$.

The source of LF in human malignant primary and metastatic bone tumours has not been still clarified. It is noteworthy that LF expresses a high affinity for iron, an essential nutrient for cells that are dividing rapidly such as tumour cells, being involved in metabolic processes such as oxydative phosphorylation and RNA and DNA synthesis [4344]. So, neoplastic elements might produce LF in order to make a greater amount of iron available for their turnover, as we previously suggested [14,18,37-38,45]. Otherwise, the localization of LF in neoplastic cells may not represent the results of an intrinsic cellular synthesis, being instead determined by a defective or functionally impaired LF-receptors, elsewhere demonstrated in human neoplastic cell lines [39-40]. However, some additional functions for LF have been suggested in human carcinogenesis, such as programmed cell death, inhibition of angiogenesis, regulation of cell cycle protein expression and activation of immune cells [2,22-23]. Indeed, LF is able to trigger the apoptotic process by the activation of caspases 3 and 8 as well as the FAS signaling pathway $[25,46]$. In addition, LF has been considered a protein able to block the endothelial function in vitro and in vivo, probably by the stimulation for IL-18 production [23,47-48]. Finally, it has been suggested that LF promoted growth arrest either at the G1 to $S$ transition in breast cancer cells [47] as well as at the G0-G1 checkpoint in oral and neck cancer cells [48]. Taking into consideration the above mentioned anticancer functions of LF, several studies proposed an exogenous nutritional and therapeutic treatment with LF and its derivatives [49-53]. None of these studies, however, reported a consistent outcome with regard to the mechanisms underlying the anticancer effects of LF. Therefore, we probably need additional analyses concerning new applications of LF in clinical oncology either for its nutraceutical function either for its capability to potentiate chemotherapy.

\section{Competing Interests}

The authors have declared that no competing interests exist. 
Citation: Ieni A, Barresi V, Speciale G, Caruso RA, Tuccari G (2015) Immunohistochemical Investigation of Lactoferrin in Human Bone Primary and Metastatic Tumours. Int J Lab Med Res 1: 105. doi: http://dx.doi.org/10.15344/2455-4006/2015/105

Page 5 of 6

\section{Author Contributions}

All the authors substantially contributed to the study conception and design as well as the acquisition and interpretation of the data and drafting the manuscript.

\section{References}

1. Lönnerdal B, lyer S (1995) Lactoferrin: molecular structure and biological function. Annu Rev Nutr 15: 93-110.

2. Tuccari G, Barresi G (2011) Lactoferrin in human tumours: immunohistochemical investigations during more than 25 years. Biometals 24: 775-784

3. Garré C, Bianchi-Scarrá G, Sirito M, Musso M, Ravazzolo R (1992) Lactoferrin binding sites and nuclear localization in K562(S) cells. J Cell Physiol 153: 477-482.

4. Naidu AS, Miedzobrodzki J, Andersson M, Nilsson LE, Forsgren A, et al (1990) Bovine lactoferrin binding to six species of coagulase-negative staphylococci isolated from bovine intramammary infections. J Clin Microbiol 28: 2312-2319.

5. Schaible UE, Collins HL, Priem F, Kaufmann SH (2002) Correction of the iron overload defect in beta-2-microglobulin knockout mice by lactoferrin abolishes their increased susceptibility to tuberculosis. J Exp Med 196: 1507-1513.

6. Farnaud S, Evans RW (2003) Lactoferrin--a multifunctional protein with antimicrobial properties. Mol Immunol 40: 395-405

7. Ikeda M, Sugiyama K, Tanaka T, Tanaka K, Sekihara H, et al. (1998) Lactoferrin markedly inhibits hepatitis $C$ virus infection in cultured human hepatocytes. Biochem Biophys Res Commun 245: 549-553.

8. Cirioni O, Giacometti A, Barchiesi F, Scalise G (2000) Inhibition of growth of Pneumocystis carinii by lactoferrins alone and in combination with pyrimethamine, clarithromycin and minocycline. J Antimicrob Chemother 46: 577-582.

9. Kimura M, Nam MS, Ohkouchi Y, Kumura H, Shimazaki Ki, et al. (2000) Antimicrobial peptide of korean native goat lactoferrin and identification of the part essential for this activity. Biochem Biophys Res Commun 268 333-336.

10. Omata Y, Satake M, Maeda R, Saito A, Shimazaki K, et al. (2001) Reduction of the infectivity of Toxoplasma gondii and Eimeria stiedai sporozoites by treatment with bovine lactoferricin. J Vet Med Sci 63: 187-190.

11. Brock JH (2002) The physiology of lactoferrin. Biochem Cell Biol 80: 1-6.

12. Kanyshkova TG, Buneva VN, Nevinsky GA (2001) Lactoferrin and its biological functions. Biochemistry (Mosc) 66: 1-7.

13. Legrand D, Pierce A, Elass E, Carpentier M, Mariller C, et al. (2008) Lactoferrin structure and functions. Adv Exp Med Biol 606: 163-194.

14. Ward PP, Paz E, Conneely OM (2005) Multifunctional roles of lactoferrin: a critical overview. Cell Mol Life Sci 62: 2540-2548.

15. Cornish J (2004) Lactoferrin promotes bone growth. Biometals 17: 331 335

16. Naot D, Grey A, Reid IR, Cornish J (2005) Lactoferrin--a novel bone growth factor. Clin Med Res 3: 93-101.

17. Cornish J, Naot D (2010) Lactoferrin as an effector molecule in the skeleton. Biometals 23: 425-430.

18. Damiens E, El Yazidi I, Mazurier J, Duthille I, Spik G, et al. (1999) Lactoferrin inhibits $\mathrm{G} 1$ cyclin-dependent kinases during growth arrest of human breast carcinoma cells. J Cell Biochem 74: 486-498.

19. Norrby K, Mattsby-Baltzer I, Innocenti M, Tuneberg S (2001) Orally administered bovine lactoferrin systemically inhibits VEGF(165)-mediated angiogenesis in the rat. Int J Cancer 91: 236-240.

20. Giuffrè G, Barresi V, Skliros C, Barresi G, Tuccari G (2007) Immunoexpression of lactoferrin in human sporadic renal cell carcinomas. Oncol Rep 17: 1021-1026.

21. Mason DY, Taylor CR (1978) Distribution of transferrin, ferritin, and lactoferrin in human tissues. J Clin Pathol 31: 316-327.

22. Ieni A, Barresi V, Grosso M, Rosa MA, Tuccari G (2009) Lactoferrin immuno-expression in human normal and neoplastic bone tissue. J Bone Miner Metab 27: 364-371.

23. Ieni A, Barresi V, Grosso M, Rosa MA, Tuccari G (2009) Immunolocalization of lactoferrin in cartilage-forming neoplasms. J Orthop Sci 14: 732-737.
24. Antonio I, Valeria B, Maddalena G, Giovanni T (2010) Immunohistochemical evidence of lactoferrin in human embryo-fetal bone and cartilage tissues. Cell Biol Int 34: 845-849.

25. Ieni A, Barresi V, Grosso M, Speciale G, Rosa MA, et al. (2011) Does lactoferrin behave as an immunohistochemical oncofetal marker in bone and cartilage human neoplasms? Pathol Oncol Res 17: 287-293.

26. Ieni A, Barresi V, Branca G, Giuffrè G, Rosa MA, et al. (2013) Immunoexpression of lactoferrin in bone metastases and corresponding primary carcinomas. Oncol Lett 5: 1536-1540.

27. Tuccari G, Villari D, Giuffrè G, Simone A, Squadrito G, et al. (2002) Immunohistochemical evidence of lactoferrin in hepatic biopsies of patients with viral or cryptogenetic chronic liver disease. Histol Histopathol 17: 1077-1083.

28. Caselitz J, Jaup T, Seifert G (1981) Lactoferrin and lysozyme in carcinomas of the parotid gland. A comparative immunocytochemical study with the occurrence in normal and inflamed tissue. Virchows Arch A Pathol Anat Histol 394: 61-73.

29. Barresi G, Tuccari G (1984) Lactoferrin in benign hypertrophy and carcinomas of the prostatic gland. Virchows Arch A Pathol Anat Histopathol 403: 59-66.

30. Charpin C, Lachard A, Pourreau-Schneider N, Jacquemier J, Lavaut MN, et al. (1985) Localization of lactoferrin and nonspecific cross-reacting antigen in human breast carcinomas. An immunohistochemical study using the avidin-biotin-peroxidase complex method. Cancer 55: 2612-2617.

31. Benaïssa M, Peyrat JP, Hornez L, Mariller C, Mazurier J, et al. (2005) Expression and prognostic value of lactoferrin mRNA isoforms in human breast cancer. Int J Cancer 114: 299-306.

32. Tuccari G, Barresi G (1985) Immunohistochemical demonstration of lactoferrin in follicular adenomas and thyroid carcinomas. Virchows Arch A Pathol Anat Histopathol 406: 67-74.

33. Barresi G, Tuccari G (1987) Iron-binding proteins in thyroid tumours. An immunocytochemical study. Pathol Res Pract 182: 344-351.

34. Cabaret V, Vilain MO, Delobelle-Deroide A, Vanseymortier L (1992) [Immunohistochemical demonstration of ceruloplasmin and lactoferrin in a series of 59 thyroid tumors]. Ann Pathol 12: 347-352.

35. Tuccari G, Barresi G, Arena F, Inferrera C (1989) Immunocytochemical detection of lactoferrin in human gastric carcinomas and adenomas. Arch Pathol Lab Med 113: 912-915.

36. Tuccari G, Rizzo A, Crisafulli C, Barresi G (1992) Iron-binding proteins in human colorectal adenomas and carcinomas: an immunocytochemical investigation. Histol Histopathol 7: 543-547.

37. Tuccari G, Rossiello R, Barresi G (1997) Iron binding proteins in gallbladder carcinomas. An immunocytochemical investigation. Histol Histopathol 12: 671-676.

38. Tuccari G, Giuffrè G, Crisafulli C, Barresi G (1999) Immunohistochemical detection of lactoferrin in human astrocytomas and multiforme glioblastomas. Eur J Histochem 43: 317-322.

39. Tuccari G, Giuffrè G, Scarf R, Simone A, Todaro P, et al. (2005) Immunolocalization of lactoferrin in surgically resected pigmented skin lesions. Eur J Histochem 49: 33-38.

40. Giuffrè G, Arena F, Scarfi R, Simone A, Todaro P, et al. (2006) Lactoferrin immunoexpression in endometrial carcinomas: relationships with sex steroid hormone receptors (ER and PR), proliferation indices (Ki-67 and AgNOR) and survival. Oncol Repo 16: 257-263.

41. Naot D, Chhana A, Matthews BG, Callon KE, Tong PC, et al. (2011) Molecular mechanisms involved in the mitogenic effect of lactoferrin in osteoblasts. Bone 49: 217-224.

42. Ieni A, Barresi V, Giuffrè G, Tuccari G (2013) Lactoferrin in Malignant Human Tumours: New Insights from an Immunohistochemical MetaAnalysis. J Analyt Oncol 2: 17-23.

43. Weinberg ED (1984) Iron withholding: a defense against infection and neoplasia. Physiol Rev 64: 65-102.

44. Ye XY, Wang HX, Liu F, Ng TB (2000) Ribonuclease, cell-free translationinhibitory and superoxide radical scavenging activities of the iron-binding protein lactoferrin from bovine milk. Int J Biochem Cell Biol 32: 235-241.

45. Qiu J, Hendrixson DR, Baker EN, Murphy TF, St Geme JW 3rd, et al. (1998) Human milk lactoferrin inactivates two putative colonization factors expressed by Haemophilus influenzae. Proc Natl Acad Sci U S A 95: $12641-12646$ 
Citation: Ieni A, Barresi V, Speciale G, Caruso RA, Tuccari G (2015) Immunohistochemical Investigation of Lactoferrin in Human Bone Primary and Metastatic Tumours. Int J Lab Med Res 1: 105. doi: http://dx.doi.org/10.15344/2455-4006/2015/105

46. Garré C, Bianchi-Scarrá G, Sirito M, Musso M, Ravazzolo R (1992) Lactoferrin binding sites and nuclear localization in K562(S) cells. J Cell Physiol 153: 477-482.

47. Penco S, Scarfi S, Giovine M, Damonte G, Millo E, et al. (2001) Identification of an import signal for, and the nuclear localization of, human lactoferrin. Biotechnol Appl Biochem 34: 151-159.

48. Legrand D, Vigié K, Said EA, Elass E, Masson M, et al. (2004) Surface nucleolin participates in both the binding and endocytosis of lactoferrin in target cells. Eur J Biochem 271: 303-317.

49. Pepe G, Tenore GC, Mastrocinque R, Stusio P, Campiglia P (2013) Potential anticarcinogenic peptides from bovine milk. J Amino Acids 2013: 939804.

50. Yin CM, Wong JH, Xia J, Ng TB (2013) Studies on anticancer activities of lactoferrin and lactoferricin. Curr Protein Pept Sci 14: 492-503.

51. Shi H, Li W (2014) Inhibitory effects of human lactoferrin on U14 cervical carcinoma through upregulation of the immune response. Oncol Lett 7: 820-826.

52. Ebrahim F, Shankaranarayanan JS, Kanwar JR, Gurudevan S, Krishnan UM, et al. (2014) Identification of unprecedented anticancer properties of high molecular weight biomacromolecular complex containing bovine lactoferrin (HMW-bLf). PLoS One 9: e106568.

53. Zhang Y, Lima CF, Rodrigues LR (2014) Anticancer effects of lactoferrin: underlying mechanisms and future trends in cancer therapy. Nutr Rev 72: 763-773. 